\title{
Auditory Speech Perception Development in Relation to Patient's Age with Cochlear Implant
}

\author{
Grace Kelly Seixas Ciscare ${ }^{1}$ Erika Barioni Mantello ${ }^{1}$ Carla Aparecida Urzedo Fortunato-Queiroz ${ }^{1}$ \\ Miguel Angelo Hyppolito ${ }^{1}$ Ana Cláudia Mirândola Barbosa dos Reis ${ }^{1}$ \\ ${ }^{1}$ Department of Ophthalmology, Otorhinolaryngology, Head and
Neck Surgery, Ribeirão Preto Medical School, Universidade de São
Paulo, Ribeirão Preto, São Paulo, Brazil \\ Int Arch Otorhinolaryngol 2017;21:206-212. \\ Address for correspondence Erika Barioni Mantello, PhD, Department \\ of Ophthalmology, Otorhinolaryngology Head and Neck Surgery, \\ Ribeirão Preto Medical School, Universidade de São Paulo, Av \\ Bandeirantes, 3600, Campus Ribeirão Preto, SP, 14049-900, Brazil \\ (e-mail: erikafga@yahoo.com.br).
}

\begin{abstract}
Introduction A cochlear implant in adolescent patients with pre-lingual deafness is still a debatable issue.

Objective The objective of this study is to analyze and compare the development of auditory speech perception in children with pre-lingual auditory impairment submitted to cochlear implant, in different age groups in the first year after implantation.

Method This is a retrospective study, documentary research, in which we analyzed 78 reports of children with severe bilateral sensorineural hearing loss, unilateral cochlear implant users of both sexes. They were divided into three groups: G1, 22 infants aged less than 42 months; G2, 28 infants aged between 43 to 83 months; and G3, 28 older than 84 months. We collected medical record data to characterize the patients, auditory thresholds with cochlear implants, assessment of speech perception, and auditory skills. Results There was no statistical difference in the association of the results among groups G1, G2, and G3 with sex, caregiver education level, city of residence, and speech perception level. There was a moderate correlation between age and hearing aid use time, age and cochlear implants use time. There was a strong correlation between age

\section{Keywords}

- cochlear implantation

- auditory perception

- age groups

- deafness

- rehabilitation and the age cochlear implants was performed, hearing aid use time and age $\mathrm{Cl}$ was performed.

Conclusion There was no statistical difference in the speech perception in relation to the patient's age when cochlear implant was performed. There were statistically significant differences for the variables of auditory deprivation time between G3 - G1 and $G 2$ - G1 and hearing aid use time between G3 - G2 and G3 - G1.
\end{abstract}

\section{Introduction}

Hearing is a pre-requisite for language acquisition and development. Thus, hearing and language are interrelated and interdependent functions. One of the main disorders that may interfere with the development of language and speech is hearing impairment. The American Speech-Language-Hearing Association (ASHA) considers that hearing impairments represent $60 \%$ of the communication disorders, with congenital hearing loss

received

February 24, 2016

accepted

April 21, 2016

published online

July 20, 2016 10.1055/s-0036-1584296. ISSN $1809-9777$. considered the most frequent and most prevalent among those routinely screened in preventive health programs. ${ }^{1}$

Early diagnosis and immediate intervention are essential to ensure the child with hearing loss a better development of auditory, language and cognitive skills, as it is a highly disabling disorder, considering its effects on communication. ${ }^{2}$

The cochlear implant $(\mathrm{CI})$ is considered the most effective technological resource for the treatment of severe or profound sensorineural pre-lingual hearing impairment
Copyright $\odot 2017$ by Thieme Revinter

Publicações Ltda, Rio de Janeiro, Brazil
License terms

(®) $\Theta \circledast$ 
currently available. ${ }^{3}$ This is an intervention whose effects and results for communicative skills in children are obtained over the years. ${ }^{4}$ To introduce the benefits of early implantation, the gap between the age of language development and chronological age should be minimized and auditory information should be introduced during sensitive periods of hearing and language development. ${ }^{5}$

Sensitive periods, also known as critical, are specific periods of brain development, since these steps should coincide with exposure to certain sensory experiences, resulting in rapid acquisition of new skills, which are impossible or very difficult to be acquired in other stages. ${ }^{6}$ Thus, auditory experiences combined with information from other senses optimize the construction of oral language and concept formation. ${ }^{7-9}$

In the sensitive period, the central auditory system can be modified depending on the quantity and quality of captured external stimuli. The richer the stimuli, the greater the level of connections between inner ear and cortex. The child who does not receive proper language stimulation during the first two or three years of life will hardly have his/her hearing and language potential fully developed. ${ }^{10}$ Thus, early adaptation to cochlear implant before structural and functional changes in the brain is important to ensure proper development of the auditory system and therefore language. ${ }^{11,12}$

Assessment and follow-up of these children's language skills are important for several reasons, such as to verify the effectiveness of $\mathrm{CI}$ as well as the auditory performance progress. ${ }^{7}$

In recent studies, communicative skills improved for many of the subjects after CI was performed. In adults, after cochlear implant, stimulation allows recognition of sentences with and without visual support. Children, after cochlear implantation, become responsive to instrumental tests, recognize voices and words. ${ }^{13}$ The age at surgery is an important variable to be considered. Studies show that children implanted earlier achieve better performance in auditory perception, incidental language acquisition, and speech intelligibility. ${ }^{7,14,15}$

Short-term results, measured during the first years of $\mathrm{Cl}$ use in children with pre-lingual hearing impairment, have been fully described in the literature. In general, the results of these studies demonstrated the unquestionable benefits using $\mathrm{CI}$, whether within receptive or expressive language in the academic learning process or in social and emotional areas. ${ }^{4,13,15}$

Several factors described in the literature, such as etiology, age at implantation, presence of residual hearing, effective auditory rehabilitation, family participation in the therapeutic process, may potentially contribute to the variability in the performance of children using $\mathrm{CI}^{4,16}$

There has been an increase in the literature of studies seeking for behavioral and objective procedures for assessing candidates for cochlear implants as well as for monitoring auditory, speech, and language development in children using $\mathrm{CI}$.

Auditory perception tests and cortical auditory evoked potentials have proven to be promising for both the candidate's development prognosis to $\mathrm{CI}$ and follow-up stage.

Cortical auditory evoked potentials are considered biomarkers of central auditory patterns maturation and are able to infer about neurophysiologic changes after intervention, as well as infer about the development of auditory skills., ${ }^{77}$ The P1 component latency of cortical auditory potentials was established as a biomarker to assess the central auditory system maturation in children. Latency changes in P1, due to increasing age, reflect the maturation of central auditory pathways occurring (at least partly) in response to auditory stimulation. 7,12

In general, a child with a hearing impairment who receives stimuli through a cochlear implant within the first 3.5 years of life will have P1 latency values within the normal range in the first 6-8 months after implant activation; it was also shown that children who have had early access to sounds have better scores on speech recognition in an open setting in comparison to those who have had auditory deprivation for longer periods. ${ }^{7}$

Cochlear implants in adolescent patients with pre-lingual deafness is still a debatable issue, and there is no consensus or scientific evidence of the eligibility criteria to ensure better results in this age group. ${ }^{18}$

Therefore, this study aimed to analyze and compare the development of auditory speech perception in children with pre-lingual hearing impairment submitted to $\mathrm{Cl}$, in different age groups in the first year after implant.

\section{Method}

This research was approved by the Ethics Committee of the involved institution, registered under number 6331/2007.

It was a retrospective, documentary research conducted through the analysis of medical records, with data collected from the Medical Archival Service of the institution.

The study analyzed 78 records of children with profound bilateral sensorineural hearing loss, unilateral cochlear implant users of both sexes. For the participants' selection, we used the following inclusion criteria: children using unilateral cochlear implant, aged 12-84 months; CI use for at least 12 months; children without any kind of psychological and neurological impairment, assessed by a specialist.

We divided the subjects into three groups: G1, composed of 22 implanted children aged less than 42 months; G2, 28 implanted children aged 43 months to 83 months; and G3, 28 implanted children older than 84 months.

\section{Data Collection}

The Hearing Health Program which performed CI in the research participants is part of a teaching hospital with previously established protocols and procedures, and their staff trained for proper record, thus turning it into a large database for research.

Initially, we collected data from medical records of patients to perform their characterization, with information such as gender, date of birth, city/state of origin, hearing deprivation time, hearing aid use time (HAUT) before $\mathrm{CI}$, age at cochlear implant, date of surgery, and caregiver and child education level. The data collected relating to hearing assessments performed at every visit to the Cochlear Implant Program included: a) the hearing thresholds with $\mathrm{CI}$ for frequencies between 250 and $6 \mathrm{kHz}$, acquired in open field, with the speakers at 45 azimuth, $80 \mathrm{~cm}$ distant from the implanted ear; b) speaking skills through the analysis of the 
Table 1 Criteria established in this study to categorize auditory speech perception level

\begin{tabular}{|l|l|l|}
\hline Skill & $\begin{array}{l}\text { Result in percentage } \\
\text { between }\end{array}$ & Category \\
\hline \multirow{2}{*}{ Detection } & $0-50 \%$ & 1 \\
\cline { 2 - 3 } & $51 \%-100 \%$ & 2 \\
\hline \multirow{2}{*}{ Discrimination } & $0-50 \%$ & 3 \\
\cline { 2 - 3 } & $51 \%-100 \%$ & 4 \\
\hline Recognition & $0-50 \%$ & 5 \\
\cline { 2 - 3 } & $51 \%-100 \%$ & 6 \\
\hline Comprehension & $0-50 \%$ & 7 \\
\cline { 2 - 3 } & $51 \%-100 \%$ & 8 \\
\hline
\end{tabular}

questionnaire Meaningful Use of Speech Scale (MUSS) ${ }^{19,20}$; c) auditory skills, considering: the responses recorded in the patient record for the questionnaire Infant-Toddler Meaningful Auditory Integration Scale (IT-MAIS), ${ }^{21,22}$ and the speech perception assessment, performed according to the applied test and adapted to the age of the subject, considering children aged up to 5 years and 11 months: Phonemes and Words Recognition Index ${ }^{23}$ and/or Assessment Test for Minimum Hearing Capacity - TACAM ${ }^{24}$; and the children aged from six years, the Words Recognition Index: Disyllables List, $^{25}$ and/or Assessment of Auditory Behavior through four Glendonald Auditory Screening Procedure (GASP) tests: detection of Ling sounds, discrimination of vowel length, word recognition, and comprehension of simple sentences. ${ }^{26}$

Due to the variety of tests used to assess speech perception and because of the age variability of the sample, there was a need to establish categories herein named Speech Perception Level (SPL), classified according to the development level of the auditory speech perception of the child. The established category ranged from 0 (lowest level of speech perception) to 8 (highest level of speech perception).

Thus, - Table 1 describes the criteria for categorizing the level of auditory speech perception of the participating children. As criteria, we established that the value of auditory speech perception level increases as does the complexity of auditory skills.

\section{Statistical Analysis}

After the description of data, we used a chi-square test to verify the association of the subject's speech perception level (SPL) results with the school level of caregivers and genders. To verify the SPL relationship with age at $\mathrm{CI}$, auditory thresholds mean, auditory deprivation time, and cochlear implant use time, we used Spearman's correlation. For the interpretation of Spearman's correlation coefficient, we considered the following values: $0-0.2=$ very weak correlation; $0.2-0.5=$ weak correlation; $0.5-0.7=$ moderate correlation; $0.7-0.9=$ strong correlation; and 0.9-1 = excellent correlation.

We also used Analysis of Variance - ANOVA $^{27}$ to compare information between groups and Tukey post test to highlight the differences among the groups. All results were obtained using software SAS 9.2. And the graphics were built with the $\mathrm{R}$ program, version $3.0 .^{28}$

\section{Results}

Of the 78 patients participating in the study, $56.41 \%$ were female and $43.59 \%$ male. - Table 2 shows the mean and standard deviation of variables: hearing deprivation time, hearing aid use time, participant's age at $\mathrm{CI}$ surgery, $\mathrm{CI}$ use time, and auditory thresholds with $\mathrm{CI}$ per group.

The school level of the subjects ranged from preschool to regular high school, with $88.15 \%$ of the participants attending regular school and $11.85 \%$ attending a special school. Of the 78 participants, $16.95 \%$ attended the first year of regular elementary school during the data collection period.

As for caregiver education level, 3.33\% had incomplete elementary education, $10 \%$ complete elementary education, $6.67 \%$ incomplete high school, $56.67 \%$ completed high school, $3.33 \%$ incomplete higher education, and 20\% completed higher education.

As for the analysis of SPL in relation to the groups, - Table 3 shows the number of patients and percentage, according to the Group and SPL category. It is worth noting, in this table, that the total sample was 67 patients, 15 patients in G1, 26 in G2, and 26 in G3. These numbers differ from the original sample number $(n=78)$, because the data for this analysis (SPL) was not found in the medical record of 11 patients (seven belonging to G1, two belonging to $\mathrm{G} 2$, and two belonging to G3).

Table 2 Mean and standard deviation of the studied values: auditory deprivation time, hearing aid use time, cochlear implant use time, and hearing threshold with cochlear implant, per group

\begin{tabular}{|c|c|c|c|c|c|c|c|c|c|c|}
\hline \multirow[t]{2}{*}{ Group } & \multicolumn{2}{|c|}{$\begin{array}{l}\text { ADT } \\
\text { (years) }\end{array}$} & \multicolumn{2}{|c|}{ HAUT (years) } & \multicolumn{2}{|c|}{$\begin{array}{l}\text { Age with } \mathrm{Cl} \\
\text { (years) }\end{array}$} & \multicolumn{2}{|c|}{$\begin{array}{l}\text { CIUT } \\
\text { (years) }\end{array}$} & \multicolumn{2}{|c|}{$\begin{array}{l}\text { AT com } \mathrm{Cl} \\
\text { (dBHL) }\end{array}$} \\
\hline & Mean & sd & Mean & sd & Mean & sd & Mean & sd & Mean & sd \\
\hline G1 & 1.8 & 0.8 & 1 & 0.7 & 2.8 & 0.7 & 4.1 & 1.7 & 40.7 & 21.4 \\
\hline$G 2$ & 2.8 & 1.4 & 2.1 & 1.5 & 5.2 & 1.7 & 4 & 1.7 & 36.2 & 12.4 \\
\hline G3 & 3 & 1.7 & 6 & 3.1 & 8.8 & 1.7 & 4.4 & 1.3 & 34.2 & 12 \\
\hline
\end{tabular}

Abbreviations: ADT, Auditory Deprivation Time; AT with Cl, Auditory Threshold with Cochlear Implant; Cl, Cochlear Implant; CIUT, cochlear implant use time; dBHL, decibel Hearing Level; HAUT, hearing aid use time; sd, standard deviation. 
Table 3 Results description of auditory speech perception level among studied groups

\begin{tabular}{|c|c|c|c|c|}
\hline \multirow{2}{*}{$\begin{array}{l}\text { Category of } \\
\text { auditory speech } \\
\text { perception level }\end{array}$} & \multicolumn{3}{|l|}{ Groups } & \multirow[b]{2}{*}{ Total } \\
\hline & G1 & G2 & G3 & \\
\hline 1 & - & $\begin{array}{l}2 \\
2.99 \%\end{array}$ & $\begin{array}{l}1 \\
1.49 \%\end{array}$ & $\begin{array}{l}3 \\
4.48 \%\end{array}$ \\
\hline 2 & $\begin{array}{l}2 \\
2.99 \%\end{array}$ & $\begin{array}{l}5 \\
7.46 \%\end{array}$ & $\begin{array}{l}4 \\
5.97 \%\end{array}$ & $\begin{array}{l}11 \\
16.42 \%\end{array}$ \\
\hline 3 & - & $\begin{array}{l}1 \\
1.49 \%\end{array}$ & $\begin{array}{l}4 \\
5.97 \%\end{array}$ & $\begin{array}{l}5 \\
7.46 \%\end{array}$ \\
\hline 4 & $\begin{array}{l}1 \\
1.49 \%\end{array}$ & $\begin{array}{l}1 \\
1.49 \%\end{array}$ & $\begin{array}{l}5 \\
7.46 \%\end{array}$ & $\begin{array}{l}7 \\
10.44 \%\end{array}$ \\
\hline 5 & $\begin{array}{l}3 \\
4.48 \%\end{array}$ & $\begin{array}{l}2 \\
2.99 \%\end{array}$ & $\begin{array}{l}2 \\
2.99 \%\end{array}$ & $\begin{array}{l}7 \\
10.46 \%\end{array}$ \\
\hline 6 & $\begin{array}{l}1 \\
1.49 \%\end{array}$ & $\begin{array}{l}1 \\
1.49 \%\end{array}$ & $\begin{array}{l}3 \\
4.48 \%\end{array}$ & $\begin{array}{l}5 \\
7.46 \%\end{array}$ \\
\hline 7 & $\begin{array}{l}2 \\
2.99 \%\end{array}$ & $\begin{array}{l}10 \\
14.92 \%\end{array}$ & $\begin{array}{l}3 \\
4.48 \%\end{array}$ & $\begin{array}{l}15 \\
22.39 \%\end{array}$ \\
\hline 8 & $\begin{array}{l}6 \\
8.95 \%\end{array}$ & $\begin{array}{l}4 \\
5.97 \%\end{array}$ & $\begin{array}{l}4 \\
5.97 \%\end{array}$ & $\begin{array}{l}14 \\
20.89 \%\end{array}$ \\
\hline Total & $\begin{array}{l}15 \\
22.39 \%\end{array}$ & $\begin{array}{l}26 \\
38.80 \%\end{array}$ & $\begin{array}{l}26 \\
38.81 \%\end{array}$ & $\begin{array}{l}67 \\
100 \%\end{array}$ \\
\hline
\end{tabular}

Abbreviations: G1, Group 1; G2, Group 2; G3, Group 3.

There was no evidence of statistical difference using the chi-square test when we performed the association of the results among groups $\mathrm{G} 1, \mathrm{G} 2$, and G3 with sex ( $p=0.7465)$, caregiver education level $(p=0.5210)$, city of residence $(p=0.3207)$ and SPL $(p=0.1148)$. There was also no significant difference when combining SPL with $\operatorname{sex}(p=0.839)$ and SPL with the city of origin and where speech therapy ( $p=0763$ ) was held, using the chi-square test.

In our search for SPL correlation with the proposed variables, we observed Spearman's correlation coefficients for the proposed variables, with moderate correlation between age and hearing aid use time, age and CI use; strong correlation between age and age when $\mathrm{CI}$ was performed, hearing aid use time and age when $\mathrm{CI}$ was performed (-Table 4 ).
Other variables, such as age, hearing deprivation time, and speech perception level showed weak or very weak correlations, as seen in - Table 4.

When comparing the variables hearing deprivation time, hearing aid use time in relation to the groups through ANOVA statistical analysis, there was evidence of statistical difference, specified by Tukey post test. Thus, for the hearing deprivation time variable, there was evidence of a statistical difference between G3 - G1 and G2 - G1 $(p=0.005)$ and for the variable hearing aids use time between G3 - G2 and G3 - G1 ( $p<0.0001)$. The profile of each group regarding the variables in the study are shown in -Figs. 1 and 2.

As for the variables, CI use time $(p=0.538)$ and auditory thresholds mean with $\mathrm{CI}(p=0.328)$, was found no evidence of statistically significant difference, through ANOVA.

\section{Discussion}

Studies have shown that education level of the caregiver is a determining factor in the child's mental development and is directly related to the variety of stimulation and interaction with them. ${ }^{29-31}$ As for education level of the caregiver in this study, $56.67 \%$ of the subjects had completed high school, followed by those with higher education (20\%). Yehudai et $\mathrm{al}^{32}$ state that the socio-demographic parameter, highlighting parental education, a variable that the health system cannot control, significantly influences the results after implantation, since accessibility to speech sounds, achieved after $\mathrm{Cl}$ activation, must be integrated with the possibilities of stimulation available in the environment throughout the process (re)habilitation. Thus, the education level of the caregiver may limit the chances of the implanted child achieving the expected performance, even when identified and implanted at an early age. In this study, however, when we performed the SPL correlation with parental education, there was no evidence of statistical difference.

The education level of the children in the study could not be properly analyzed because most of them (88.15\%) attended regular education in public schools, which in many Brazilian states and towns follows the Continued Progression system. In this system, the student does not flunk from one year to the next, but at the end of cycles, in case the student does not achieve sufficient learning. Thus, it is impossible to establish

Table 4 Spearman's correlation coefficient data among auditory speech perception level, age, auditory deprivation time, hearing aid use time, cochlear implant use time, and participant age when $\mathrm{Cl}$ was performed

\begin{tabular}{|l|l|l|l|l|l|l|}
\hline Variable & ASPL & AGE & ADT & HAUT & CIUT & PAWCIWP \\
\hline NPF & 1.00000 & 0.08725 & 0.23638 & 0.17956 & 0.13411 & 0.22101 \\
\hline IDADE & 0.08725 & 1.00000 & 0.20153 & 0.64851 & 0.57433 & 0.77880 \\
\hline TPA & 0.23638 & 0.20153 & 1.00000 & 0.02710 & 0.04187 & 0.23814 \\
\hline TUSOAASI & 0.17956 & 0.64851 & 0.02710 & 1.00000 & 0.06551 & 0.75922 \\
\hline TUSOIC & 0.13411 & 0.57433 & 0.04187 & 0.06551 & 1.00000 & 0.13565 \\
\hline IDADEAOIC & 0.22101 & 0.77880 & 0.23814 & 0.75922 & 0.13565 & 1.00000 \\
\hline
\end{tabular}

Abbreviations: ADT, auditory deprivation time; ASPL, auditory speech perception level; PAWCIWP, participant age when CI was performed; TCIU, time of cochlear implant use; THAU, time of hearing aid use. 


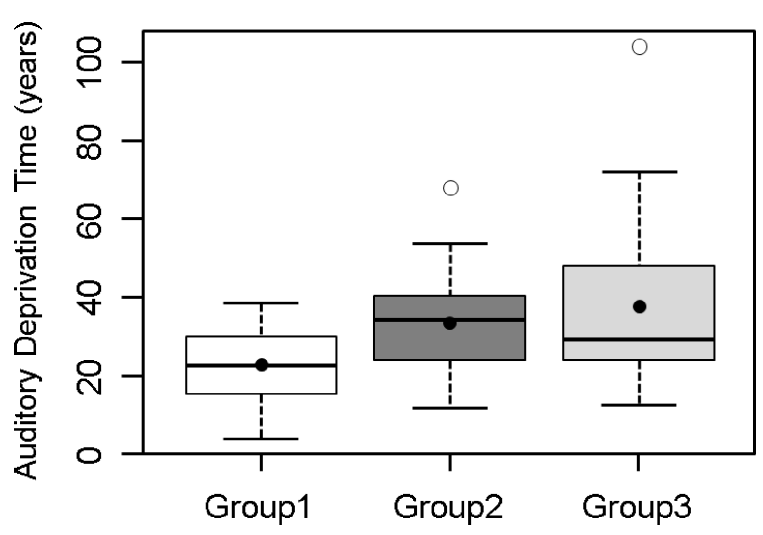

Fig. 1 Profile of each group regarding auditory deprivation time.

whether the subject's level of education matches that of his/ her age group.

The direct influence of the familýs socio-cultural level is noteworthy, specifically the caregiver's level, for hearing children's process of acquisition and development, which should be the same for children with hearing impairment. However, when data was collected from the 78 medical records, we could observe that the "evolution" of children in the intervention process depends on several inter and intra related factors. Some of them with a greater predominance of influences, such as the critical period (neural plasticity), early intervention, and systematic and effective rehabilitation process, ensured by an engaged and skilled professional.

The literature states that the earlier the implant, the better the auditory and language development of the child. ${ }^{7}$

In a comparative analysis of the data in - Table 2 , we found that the more delayed the intervention (represented by hearing deprivation time), the later the realization of the cochlear implant surgery (represented by the age at implant). The hearing impaired child should remain the minimum possible deprived of sounds. The hearing deprivation time is one of the factors that interfere the most with the development of spoken language and can even be the main cause, taking into account the particularities of each case. ${ }^{33}$

The hearing thresholds mean with $\mathrm{CI}$ for G1 was $40.7 \mathrm{~dB}$ $\mathrm{HL}$, considered high for individuals who use CI. However, in

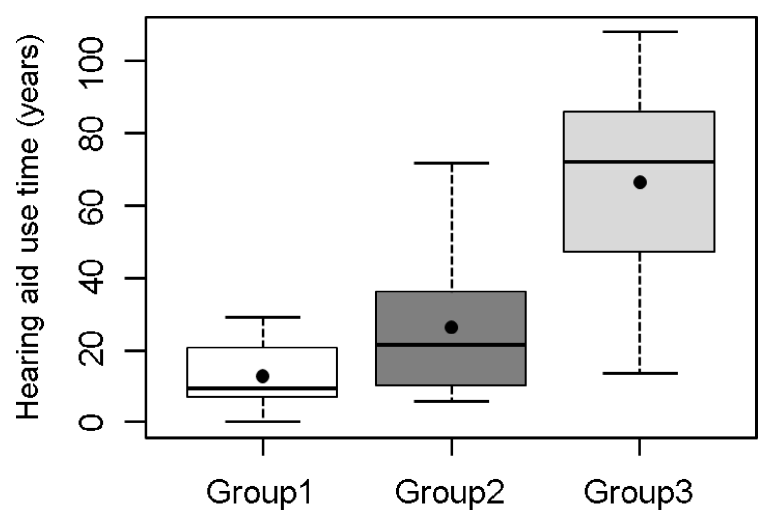

Fig. 2 Profile of each group regarding hearing aid use time. analyzing individuals separately, we noted that the thresholds recorded for subjects \#1, \#11, and \#22 significantly influenced the thresholds mean of the whole group. The high auditory thresholds found in these subjects may be justified by adjustments to the program (mapping) at the time of data collection. Some implanted children take longer to reach the desired auditory thresholds with $\mathrm{Cl}$, and this group was characterized by lower age, another variable, considering the difficulty of auditory behavioral assessment process.

Seeking to record the progress, benefits, and importance of age in the cochlear implant performance, Baumgartner et $\mathrm{al}^{34}$ performed the assessment of auditory speech perception in children implanted before and after the age of three years in a homogeneous group. All children showed improvement over time in their speech recognition skills, and children implanted before three years achieved high levels of performance. In the study, the subjects underwent intensive audiological rehabilitation programs, individually tailored after receiving cochlear implants, a reality which is not always possible in public intervention programs because of financial issues and/or family commitment, directly influencing on the positive results of the development of speech perception.

Svirsky, Teoh, and Neuburger ${ }^{35}$ developed a study in which they compared the development of language and the results of speech perception with age at cochlear implant, considering implant at the second, third, or fourth year of life. They found that children implanted between one and two years old obtained language assessment scores which were very close to the mean values of children with normal hearing. The results indicate that the average advantage of implanted children between 12 and 24 months of age was 5.7 months, in comparison with implanted children between 25 to 36 months. The group implanted earlier had an advantage over the other two groups, which indicates a decline in the language skills acquisition in relation to age at implantation, confirming the existence of a "sensitive period" for language development.

May-Mederake ${ }^{36}$ conducted a study that revealed that children implanted before two years old perform as well as or even better than their normative peers considering the development of speech and grammar. Furthermore, the effect of age on grammar and language development in children was significant in younger implanted children ( $<12$ months), who achieved higher scores than children implanted after 12 months. The fact that specific tests have been applied in this population can justify the fact that the findings are not in line with the ones of this study. The established methodological differences between investigations may be a key to the findings, whether they agree or do not with the literature.

As for patient's age at the moment of speech perception assessment, studies have shown that older subjects and with greater hearing deprivation time present poorer performance in comparison to those subjects with opposite characteristics, ${ }^{14}$ which may be related to auditory sensory deprivation time, since the literature indicates that this aspect really influences the performance of pre-lingual implanted.

In addition, studies show that there is some variability in the results obtained after a period over seven years using $\mathrm{CI}^{4}{ }^{4}$ which can be explained by the longer sensory deprivation 
time and the use of less technologically advanced devices found in the first generation of implanted children, which can contribute decisively to the existence of this variability.

A study by Souza et $\mathrm{al}^{18}$ with adolescents aged 10 to 17 years and 11 month patients with pre-lingual hearing impairment revealed that speech perception improved substantially two years after using $\mathrm{CI}$, achieving high levels of vowels and sentences recognition in open and closed settings.

There was no evidence of statistical difference when SPL results were associated with gender and caregiver education level.

In searching for SPL correlation with the proposed variables, - Table 4 shows Spearman's correlation coefficients for the proposed variables. It is possible to observe a moderate correlation between age and hearing aid use time, and age and $\mathrm{Cl}$ use time. Moreover, there is strong correlation between age and age $\mathrm{Cl}$ was performed, hearing aid use time and age $\mathrm{Cl}$ was performed.

Contrary to this research, other studies ${ }^{37-39}$ in which SPL did not correlate with age concluded that the factors affecting the performance of cochlear implant users in speech perception tests are the earlier activation of $\mathrm{Cl}$ and the use of hearing aids in the contralateral ear.

Interestingly, however, studies conducted by Geers ${ }^{40}$ Nicholas, and Sedey ${ }^{37}$ and assessing the language skills of 8 and 9 year-olds revealed that the implant in 2 or 3 year-olds did not provide significantly greater benefits to the language skill level compared with children implanted at 4 or 5 years old.

Parameters for comparison are needed to verify whether the results of $\mathrm{CI}$ in relation to language and hearing development are below expected, that is, one must know the hearing and language profile of the implanted children in their different levels of development, ${ }^{41}$ through clinical examination and detailed records.

It is important to establish time benchmarks for the subject's behavioral changes facing intervention, either through the investigation of auditory thresholds, responses to speech perception tests, and results of applied inventories as they generate contributions both to the scientific community and to the protocol to be adopted by the service.

For the group implanted up to three years and six months (G1) the hearing deprivation time is directly related to the low age, and changes in auditory health policy afforded by public health policies, especially by the organization of health care networks that prioritize organization and implementation of State Networks for Hearing Health, promoting early diagnosis and intervention. Follow-up with speech therapists in the city of origin has become increasingly effective, demonstrated by the patients' good hearing and language development. This reinforces the importance of the care network and, especially, the interaction of CI program staff with rehabilitative speech therapists from the participant's city of origin. In addition, the performance of universal screening was established as ideal, and is recommended by all professionals in the area. ${ }^{42}$

Efforts have been made by government agencies and professionals toward diagnosing as early as possible. The challenge is the intervention process, with regards to fast access to technological resources applied to deafness (hearing aids, frequency modulated systems, $\mathrm{CI}$, and others) available when needed and especially to specialized services aimed at re(habilitation) with qualified and committed professionals.

\section{Conclusion}

There was no evidence of statistical difference in relation to speech perception development with the patient's age when cochlear implant was performed. There was evidence of statistical difference for the variables, hearing deprivation time among $G 3$ - $G 1$ and $G 2$ - $G 1$, and hearing aids use time for G3 - G2 and G3 - G1.

We observed moderate correlation between age and hearing aids use time, age and $\mathrm{Cl}$ use time, and a strong correlation between age and age $\mathrm{CI}$ was performed, hearing aid use time and age $\mathrm{Cl}$ was performed.

\section{References}

1 American Speech-Language-Hearing Association. Joint Committee on Infant Hearing. 1994 position statement. ASHA 1994; 36(12):38-41

2 Pinto MM, Raimundo JC, Samelli AG, et al. Idade no diagnóstico e no início da intervenção de crianças deficientes auditivas e serviço público de saúde auditiva brasileiro. Arquivos Int Otorrinolaringol 2012;16:44-49

3 Niparko JK, Tobey EA, Thal DJ, et al; CDaCl Investigative Team. Spoken language development in children following cochlear implantation. JAMA 2010;303(15):1498-1506

4 Tanamati LF, Costa AO, Bevilacqua MC. Resultados a longo prazo com o uso do implante coclear em crianças: Revisão sistemática. Arquivos Int Otorrinolaringol 2011;15:365-375

5 Pinto ESM, Lacerda CBF, Porto PRC. Comparação entre os questionários IT-MAIS e MUSS com vídeo-gravação para avaliação de crianças candidatas ao implante coclear. Rev Bras Otorrinolaringol 2008;74:91-98

6 Klein K, Rapin I. Perda intermitente da audição de condução e desenvolvimento da linguagem. In: Bishop D, Morgford K. Desenvolvimento da linguagem em circunstâncias excepcionais. Rio de Janeiro: Revinter; 2002:123-143

7 Sharma A, Nash AA, Dorman M. Cortical development, plasticity and re-organization in children with cochlear implants. J Commun Disord 2009;42(4):272-279

8 Sharma A, Tobey E, Dorman M, et al. Central auditory maturation and babbling development in infants with cochlear implants. Arch Otolaryngol Head Neck Surg 2004;130(5):511-516

9 Thai-Van H, Veuillet E, Norena A, Guiraud J, Collet L. Plasticity of tonotopic maps in humans: influence of hearing loss, hearing aids and cochlear implants. Acta Otolaryngol 2010;130(3):333-337

10 Zocoli AMF, Riechel FC, Zeigelboim BS, Marques JM. Audição: abordagem do pediatra a cerca dessa temática. Rev Bras Otorrinolaringol 2006;72:617-623

11 Quittner AL, Leibach P, Marciel K. The impact of cochlear implants on young deaf children: new methods to assess cognitive and behavioral development. Arch Otolaryngol Head Neck Surg 2004; 130(5):547-554

12 Kral A, Sharma A. Developmental neuroplasticity after cochlear implantation. Trends Neurosci 2012;35(2):111-122

13 Geers AE, Sedey AL. Language and verbal reasoning skills in adolescents with 10 or more years of cochlear implant experience. Ear Hear 2011;32(1, Suppl)39S-48S

14 Angelo TCS, Bevilacqua MC, Moret ALM. Percepção da fala em deficientes auditivos pré-linguais usuários de implante coclear. Pró Fono R Atual Cient 2010;22:275-280 
15 Uziel AS, Sillon M, Vieu A, et al. Ten-year follow-up of a consecutive series of children with multichannel cochlear implants. Otol Neurotol 2007;28(5):615-628

16 Ruffin CV, Kronenberger WG, Colson BG, Henning SC, Pisoni DB. Long-term speech and language outcomes in prelingually deaf children, adolescents and young adults who received cochlear implants in childhood. Audiol Neurootol 2013;18(5):289-296

17 Almeida G, Lewis DR. Maturação auditiva central e desenvolvimento do balbucio em crianças usuárias de implante coclear. Rev CEFAC 2012;14(6):1096-1097

18 Souza IPS, Brito Rd, Bento RF, Gomez MVSG, Tsuji RK, HausenPinna M. Speech perception in adolescents with pre-lingual hearing impairment with cochlear implants. Braz J Otorhinolaryngol 2011;77(2):153-157

19 Robbins AM, Osberger MJ. Meaningful Use of Speech Scale (MUSS). Indianopolis: Indiana University School of Medicine; 1990

20 Nascimento LT. Uma Proposta de Avaliação da Linguagem Oral [dissertation]. Bauru: Hospital de Pesquisa e Reabilitação de Lesões Lábio-Palatais, Universidade de São Paulo; 1997

21 Zimmerman-Phillips S, Osberger MJ, Robbins AM. InfantToddler: Meaningful Auditory Integration Scale (IT-MAIS). Sylmar, Advanced Bionics Corporation; 1997

22 Castiquini EAT, Bevilacqua MC. Escala de integração auditiva significativa: procedimento adaptado para a avaliação da percepção da fala. Rev Soc Bras Fonoaudiol 2000;4(6):51-60

23 Delgado EMC, Bevilacqua MC. Lista de palavras como procedimento de avaliação da percepção dos sons da fala para crianças deficientes auditivas. Pró Fono R Atual Cient 1999;11:59-64

24 Orlandi ACL, Bevilacqua MC. Deficiência auditiva profunda nos primeiros anos de vida: procedimento para a avaliação da percepção de fala. Pró Fono R Atual Cient 1998;10:87-91

25 Lacerda AP. Audiologia clínica. Rio de Janeiro: Guanabara Koogan; 1976

26 Bevilacqua MC, Tech EA. Elaboração de um procedimento de avaliação de percepção de fala em crianças deficientes auditivas profundas a partir de cinco anos de idade. In: Marchesan IQ Zorzi JM, Gomes ICD. Tópicos em Fonoaudiologia. São Paulo: Lovise; 1996:24-32

27 Montgomery DC. Design and Analysis of Experiments. New York: John Wiley\& Sons, Inc; 2000

28 SAS Institute. SAS/STAT: User's Guide. Version 9.2. Cary: SAS Institute; 2009
29 Ceballos AGC, Cardoso C. Determinantes sociais de alterações fonoaudiológicas. Rev Soc Bras Fonoaudiol 2009;14(4):441-445

30 Santos JN, Lemos SMA, Rates SPM, Lamounier JA. Habilidades auditivas e desenvolvimento de linguagem em crianças. Pró Fono R Atual Cient 2008;20(4):255-260

31 Ribas AFP, Moura MLS. Responsividade materna: aspectos biológicos e variações culturais. Psicol Reflex Crit 2007;20(3): 368-375

32 Yehudai N, Tzach N, Shpak T, Most T, Luntz M. Demographic factors influencing educational placement of the hearing-impaired child with a cochlear implant. Otol Neurotol 2011;32(6):943-947

33 Moret ALM, Bevilacqua MC, Costa OA. Implante coclear: audição e linguagem em crianças deficientes auditivas pré-linguais. Pró Fono R Atual Cient 2007;19:295-304

34 Baumgartner WD, Pok SM, Egelierler B, Franz P, Gstoettner W, Hamzavi J. The role of age in pediatric cochlear implantation. Int J Pediatr Otorhinolaryngol 2002;62(3):223-228

35 Svirsky MA, Teoh SW, Neuburger H. Development of language and speech perception in congenitally, profoundly deaf children as a function of age at cochlear implantation. Audiol Neurootol 2004; 9(4):224-233

36 May-Mederake B. Early intervention and assessment of speech and language development in young children with cochlear implants. Int J Pediatr Otorhinolaryngol 2012;76(7):939-946

37 Geers AE, Nicholas JG, Sedey AL. Language skills of children with early cochlear implantation. Ear Hear 2003;24(1, Suppl)46S-58S

38 Geers AE. Speech, language, and reading skills after early cochlear implantation. Arch Otolaryngol Head Neck Surg 2004;130(5): 634-638

39 Silva LAF, Couto MIV, Tsuji RK, Bento RF, Matas CG, Carvalho ACM. Auditory pathways' maturation after cochlear implant via cortical auditory evoked potentials. Braz J Otorhinolaryngol 2014;80(2): 131-137

40 Nicholas JG, Geers AE. Effects of early auditory experience on the spoken language of deaf children at 3 years of age. Ear Hear 2006; 27(3):286-298

41 Stuchi RF, Nascimento LT, Bevilacqua MC, Brito Neto RV. Linguagem oral de crianças com cinco anos de uso do implante coclear. Pró Fono R Atual Cient 2007;19:167-176

42 Lewis DR, Marone SA, Mendes BC, Cruz OL, Nóbrega Md. Multiprofessional committee on auditory health: COMUSA. Braz J Otorhinolaryngol 2010;76:121-128 